NBER WORKING PAPER SERIES

THE CHANGING SELECTIVITY OF AMERICAN COLLEGES

\author{
Caroline M. Hoxby \\ Working Paper 15446 \\ http://www.nber.org/papers/w15446 \\ NATIONAL BUREAU OF ECONOMIC RESEARCH \\ 1050 Massachusetts Avenue \\ Cambridge, MA 02138 \\ October 2009
}

The author thanks David Autor, Christopher Avery, William Bowen, Charles Clotfelter, James Hines, and Harriet Zuckerman for comments that greatly improved this paper and the larger project on which it is based. Much of the work and data-gathering for this paper was supported by a generous grant from the Mellon Foundation. The views expressed herein are those of the author(s) and do not necessarily reflect the views of the National Bureau of Economic Research.

NBER working papers are circulated for discussion and comment purposes. They have not been peerreviewed or been subject to the review by the NBER Board of Directors that accompanies official NBER publications.

(C) 2009 by Caroline M. Hoxby. All rights reserved. Short sections of text, not to exceed two paragraphs, may be quoted without explicit permission provided that full credit, including $\odot$ notice, is given to the source. 
The Changing Selectivity of American Colleges

Caroline M. Hoxby

NBER Working Paper No. 15446

October 2009

JEL No. H75,I2,J24

\begin{abstract}
$\underline{\text { ABSTRACT }}$
This paper shows that although the top ten percent of colleges are substantially more selective now than they were 5 decades ago, most colleges are not more selective. Moreover, at least 50 percent of colleges are substantially less selective now than they were then. This paper demonstrates that competition for space--the number of students who wish to attend college growing faster than the number of spaces available--does not explain changing selectivity. The explanation is, instead, that the elasticity of a student's preference for a college with respect to its proximity to his home has fallen substantially over time and there has been a corresponding increase in the elasticity of his preference for a college with respect to its resources and peers. In other words, students used to attend a local college regardless of their abilities and its characteristics. Now, their choices are driven far less by distance and far more by a college's resources and student body. It is the consequent re-sorting of students among colleges that has, at once, caused selectivity to rise in a small number of colleges while simultaneously causing it to fall in other colleges. I show that the integration of the market for college education has had profound implications on the peers whom college students experience, the resources invested in their education, the tuition they pay, and the subsidies they enjoy. An important finding is that, even though tuition has been rising rapidly at the most selective schools, the deal students get there has arguably improved greatly. The result is that the "stakes" associated with admission to these colleges are much higher now than in the past.
\end{abstract}

Caroline M. Hoxby

Department of Economics

Stanford University

Landau Building, 579 Serra Mall

Stanford, CA 94305

and NBER

choxby@stanford.edu 


\title{
The Changing Selectivity of American Colleges
}

\author{
Caroline M. Hoxby
}

If one spends time at certain colleges' events, one is likely to hear alumni exclaim that their college is so selective today that they would not be admitted were they to reapply. Similarly, one might hear parents worry that their children are forced into excessive resume polishing because American colleges are increasingly selective. These alumni and parents often assume that rising selectivity is a pervasive phenomenon, and they often also assume that it is caused by colleges' not having expanded sufficiently to accommodate the ever growing population of U.S. students with post-secondary ambitions. The latter assumption--that the supply of college places has been relatively inelastic despite a growing population of prospective students--would seem to explain rising tuition. Thus, rising selectivity and rising tuition would seem to be part of the same logical phenomenon affecting higher education.

It turns out that the above thinking is a consequence of people extrapolating from the experience of a small number of colleges such as members of the Ivy League, Stanford, Duke, and so on. These colleges have experienced rising selectivity, but their experience turns out to be the exception rather than the rule. Rising selectivity is by no means a pervasive phenomenon. Only the top ten percent of colleges are substantially more selective now than they were in 1962. Moreover, at least 50 percent of colleges are substantially less selective now than they were in 1962. Typical college-going students in the U.S. should be unconcerned about rising selectivity. If anything, they should be concerned about falling selectivity, the phenomenon they will actually experience.

Although some of the decreasing selectivity of most colleges is due to the number of places growing faster than the number of college-ready students, another explanation is also important. This other explanation--moreover-explains all of the increasing selectivity of the top ten percent of colleges, where the number of places has grown at approximately the same rate as (just slightly faster than, in fact) the number of highly qualified students. What is this "other" explanation? It is that the elasticity of a student's preference for a college with respect to its proximity to his home has fallen substantially over time and there has been a corresponding increase in the elasticity of his preference for a college with respect to its resources and peers. Put more bluntly, students used to attend a local college regardless of their abilities and its characteristics. Now, their choices are driven far less by distance and far more by a college's resources and student body. The 
change in elasticities has been especially pronounced among students who are very well qualified for college. It is the consequent re-sorting of students among colleges that has, at once, caused selectivity to rise in a small number of colleges while simultaneously causing it to fall in other colleges.

What has happened and what is happening to the market for college education is a species of globalization that has so far manifested itself mainly in the nationalization of local markets that were largely autarkic as recently as the end of World War II. (Since the process continues and has not halted at U.S. borders, "globalization" and "integration" are more apt terms than "nationalization.") The causes of integration, I will argue, are great decreases in the costs of information about students and colleges and substantial decreases in the costs of long-distance communication and transportation. Falling long-distance costs are routinely cited as causes of globalization, but the dramatically decreasing costs of information are somewhat unique to the market for college education.

The integration of the market for college education has had profound implications on which students attend which college and, thus, on selectivity. I show this in the next section of the paper. Integration has also had profound implications for colleges' resources, tuition, and subsidies for students. These implications are somewhat more complex, and I trace them in the later sections of the paper, after reviewing a few models that help us understand what to expect. For instance, I will show that, even though tuition has been rising rapidly at the most selective schools, the deal students get there has arguably improved greatly. The result is that the "stakes" associated with admission to these colleges are much higher now than in the past.

This topic relates to many issues in the economics of higher education. In this article, I attempt to provide the key evidence and key economic logic. However, a reader who is curious to see some piece of the puzzle worked out in greater detail may wish to consult Hoxby, Competitive New World: How American Colleges Learned to Compete and How They Will Change the World (forthcoming). This work also contains additional details on the data and a formal version of some theory that I summarize here. ${ }^{1}$

1 Construction of the dataset used for this paper was, in principle, straightforward but, in practice, required approximately 15 years of work. Thus, it is not surprising that previous commentators have often relied upon more anecdotal evidence. The dataset includes virtually all quantitative information on colleges' students and finances that is available for the post World War II period. Every existing college guide from 1940 


\section{The Changing Selectivity of American Colleges}

Before considering why things changed or what the implications are, let us look simply at what happened to the selectivity of American colleges. The hard evidence starts with 1960s because that is when the the SAT ${ }^{\circledR}$ and $\mathrm{ACT}^{\circledR}$ (the college entrance examinations that remain dominant today) came into widespread use. However, available measures--like students' grades, class rank, and scores on less ubiquitous exams---suggest that the 1960s were a continuation of dramatic changes that began in the 1950s.

In the figures that follow, colleges are grouped according to their selectivity in 1962. The mean SAT score or ACT score of each college (math and verbal is translated into today's national percentiles of entrance exam takers. ${ }^{2}$ That is, we are looking at absolute exam performance on a stable metric. Combined math and verbal (or comprehensive ACT) scores are used. It is important to compute statistics over scores expressed in percentile points, rather than--say--points on the SAT's 200-800 scale or the ACT's 1-36 scale. This is a because the distance between points on either exam does not correspond to a stable difference in percentiles. For instance, 100 points on the SAT between 700 and 800 is a few percentiles but 100 points between 450 and 550 is 33 percentiles! Thus, if we used points rather

onwards was scoured for data, which were generally hand-entered, combined, and reconciled. Guides include Marsh (1940), College Entrance Examination Board (1941 to 1975), Brumbaugh (1948), Irwin (1952 and 1956), Hawes (1962 and 1966), Orchard House (1962 to 2005), College Entrance Examination Board (1962 and 1967), Barron's (1964 and 1968 to 2007), Cass and Birnbaum (1964 to 1971), and Peterson's (1971 to 2000). College guides now mainly rely on the Common Data Set, based on College Board (1986 to 2007), which was also used. In addition, annual reports of the American College Testing Service (Annual Report, ACT High School Profile Report), the College Entrance Examination Board (Annual Report, College-Bound Seniors, College-Bound Juniors and Sophomores), and the National Merit Scholarship Corporation (Annual Report, The Merit Scholars, Certificate of Merit Winners) were scoured for data. All years of available administrative survey data from the Higher Education General Information System (1966 to 1986), the Integrated Postsecondary Education Data System (2008), and CASPAR (1995 and 2008) were also used. Other sources are described as they arise.

2 One converts ACT scores into SAT scores using College Entrance Examination Board (2008a), Dorans (1999), and Dorans and Schneider (1999). One converts pre-1995 SAT scores into recentered (today's) SAT scores using College Entrance Examination Board (2008). 
than percentiles, a dramatically reallocation of students among midselectivity schools that was quite important in percentile terms might be almost invisible in terms of mean scores. Similarly, much smaller reallocations of students among high-selectivity schools in percentile terms would appear to be far more important if measured in points.

Colleges are assigned to selectivity groups such as the 1st through 5th percentiles, the 6th through 10th percentiles, the second decile, the third decile, and so on up to 96th through 98th percentiles, and the 99th percentile. The ends of the distribution are broken down finely because they are especially interesting. Once assigned to a group based on its 1962 selectivity, a college stays there. Thus, if the selectivity of a group of colleges is rising, it is because the (given) set of colleges is becoming more selective. ${ }^{3}$

Figure 1 shows that, in 1962, the average student enrolled in one of the most selective 5 percent of colleges had an entrance exam score at the 90th percentile. The least selective 5 percent of four-year colleges enrolled an average student who scored at about the 50th percentile. Of course, one might ask where the rest of college entrance exam takers went. Some did not go to college at all. Some went to "no-exam colleges" that have never required students to take entrance exams, even for diagnostic purposes. Finally, some went to two-year colleges. Using surveys that include achievement and aptitude tests, I can show that two-year colleges and noexam four-year colleges were considerably less selective than the observably least selective four-year colleges. Figure 1 shows an estimated line for two-year colleges, but the samples are small and these estimates are correspondingly imprecise. ${ }^{4}$

The key fact illustrated by Figure 1 is that the market for college

3 The groups are not weighted by colleges' enrollment.

4 To get estimates for the two-year college line shown in Figure 1, I took data from Project Talent (Flanagan et al, 2001), the National Longitudinal Study of the Class of 1972 (National Center for Education Statistics, 1994), High School and Beyond (National Center for Education Statistics, 1995), the National Education Longitudinal Study 1988 (National Center for Education Statistics, 2002), and the Education Longitudinal Study 2002/06 (National Center for Education Statistics, 2007). These surveys test the achievement of their respondents and record where they enroll in college. By mapping the achievement tests onto the stable SAT percentile scores, I obtain estimates of how two-year college students would perform on the SAT or ACT, were they to take those exams. The estimates, being based on fairly small samples, are not precise. 
education became more stratified or, in more colloquial terms, "fanned-out." In the early 1960s, the most and observably least selective four-year colleges were about 40 percentiles apart. The trends at the time, if extrapolated back, suggest that the gap was a much tighter 20 percentiles a decade previously. This is consistent with the spotty 1950s data that are available. By 1985, the gap had risen to 66 percentiles. By 2007, the gap had risen to at least 76 percentiles, more if we consider two-year and noexam four-year colleges. Only colleges above the 80th percentile are as selective as they were in 1962, and only colleges above the 90th percentile are substantially more selective than they were in 1962. Strikingly, by 2007, the most selective colleges were up against the ceiling of selectivity. Their average student was scoring at the 98th percentile. This number can rise to the 99th percentile, but, once it is there, further increases in these colleges' selectivity (choosing students carefully from within the 99th percentile on grounds on other than test scores) will not be visible to us.

Of course, this fanning-out pattern does not capture all the changes in colleges during this time. For example, certain schools--such as single-sex colleges and Catholic colleges--lost popularity and became less selective for essentially exogenous social reasons. But the overall pattern is that colleges that were the most selective coming out of World War II and the 1950s became more selective in the years that followed. Colleges that were initially the least selective become less selective. Between-college differences in student aptitude rose, within-college differences in aptitude fell, and each college became more homogeneous. (For evidence on withincollege differences in student aptitude, see Hoxby, 1997 or Hoxby, forthcoming).

Although in Figure 1 and figures that follow, colleges are grouped according to their 1962 selectivity, the figures would look very similar if colleges had been grouped according to the fixed standard of their selectivity today. This is because, as is now clear, initially more selective colleges became more selective and initially less selective colleges became less selective. Thus, only a small share of colleges' ordinal positions shifted much between 1962 and 2007, even though their absolute selectivity shifted substantially.

Because many people are confused by it, it is worth noting the "dip" in nearly all college groups' trends lines that appears from the mid 1970s through the early 1980s in Figure 1. During this period, there was a real, pronounced negative shift in the entire distribution of U.S. students' achievement. It was followed by a roughly equivalent rightward shift so that the distribution is now much the same as it was in 1970. The dip shows up not just in SAT and ACT scores but in all achievement data: 
scores on the NAEP, scores on nationally popular standardized tests (Stanford 9, Iowa Test of Basic Skills, and so on). The dip has been extensively analyzed and, while it is still not fully explained, analysts have been able to show that the whole distribution shifted left and back: it was not merely that marginal students first selected into taking the exams and then selected out of taking them.

The point of this digression is that it is best, when interpreting Figure 1 , to ignore the dip. This is because the dip does not represent meaningful changes in the behavior of colleges or students--for instance, a college that kept admitting students at the same contemporary aptitude percentile would have seen a dip in absolute scores. Neither the college nor its students would have perceived this dip as a change in selectivity. (Recall that Figure 1 shows exam performance in absolute terms.) Since the distribution of U.S. students' achievement was fully out of the dip by 1990 (that is, the percentiles of the distribution had fully recovered), it may be helpful to draw a mental line connecting 1972 to 1990 on Figure 1. That mental line will show the trend without the distracting dip, and the selectivity trends will be clearer. ${ }^{5}$

\section{Falling College Selectivity Overall}

So far, I have emphasized how colleges that were initially very selective became more selective while colleges that were initially less selective experienced the opposite trend. Such a focus leads us to think about students' re-sorting themselves, and I will maintain this focus for the most of the paper. However, it is important to realize that the stratification we have seen played out against a background of declining college selectivity overall. This overall decline was caused by the number of college places growing faster over time than the population of qualified students.

Column 1 of Table 1 shows the number of high school graduates in the U.S., from 1955 to today. This number rose by 131 percent, a substantial increase. However, column 2 shows that, over the same period, the number of freshman seats in the U.S. rose by 297 percent. This suggests that the absolute standard of achievement required of a freshman who successfully competed for a seat was falling.

Of course, the standard of achievement required of a freshman could

5 See National Center for Education Statistics (2005) for evidence on the percentiles of the math and verbal achievement distributions for a nationally representative sample of 17 year olds from 1971 to 2004. The dip is visible, as is the fact that since the dip ended, the distribution has not changed much for students in the college-going achievement range. 
have been rising, despite the growth in the number of seats, if achievement of high school graduates rose fast enough between 1955 and today. We cannot know exactly how secondary school achievement changed between 1955 and 1970 because there was no national testing. However, beginning in 1970, the National Assessment of Educational Progress (NAEP) has measured the long-term trend in 12th graders' achievement on a consistent basis. Students who score Proficient on the NAEP are moderately well prepared for college. Students who score at the Basic level on the NAEP are minimally prepared for college--that is, they may have to undergo remediation even at a non-selective college because their mathematics and reading comprehension skills are limited. ${ }^{6}$

If we look at the number of freshman seats per moderately-prepared twelfth grader (column 3) or minimally-prepared twelfth grader (column 4), we see that the number of seats per prepared student has been rising steadily. Moreover, since 1975, there has been more than one seat per minimally prepared student. In short, the achievement standard for obtaining a freshman seat in the U.S. is minimal and is falling.

The number of prepared college students does not explain even the rising selectivity of the most selective colleges (categorized according to their 1962 selectivity). In 1965, there were 0.47 freshman seats in the most selective colleges for each student with a verbal SAT score of 700 (pre-1995 scale). ${ }^{7}$ In 2007, there were 0.58 freshman seats in the most selective colleges for each such student. This is because, although the most selective colleges have not expanded greatly, they have expanded more than enough to keep up with the modest growth in the number of students scoring in the very top range.

In short, re-sorting accounts for more than 100 percent of the observed

${ }^{6}$ For descriptions of the NAEP long-term trend achievement levels, see the "Reading Performance-Level Descriptions" and "Mathematics PerformanceLevel Descriptions" sections of National Center for Education Statistics (2005).

7 I chose a verbal score of 700 on the pre-1995 SAT scale because it is an absolute level of achievement that cuts off approximately the top 5 percent of SAT scorers in 1960. The math test has always been considerably less discriminating in the top end of the score range, so that published distributions of the math score cannot be used to find the top few percent. The re-centered (today's) SAT is also fairly non-discriminating at the top end of the score range. For instance, a score of 700 on the pre-1995 verbal SAT corresponds to a score of 760 on the recentered SAT. See College Entrance Examination Board (2008b). 
increase in selectivity at the most selective colleges. These colleges' selectivity would fallen slightly had re-sorting not taken place. In contrast, the decreasing selectivity of most colleges was caused both by re-sorting (which did not operate in their favor) and the number of seats growing faster than the number of qualified students.

The main purpose of this section was to demonstrate the importance of re-sorting as the explanation for rising selectivity in initially selective colleges. The competing explanation--the number of places rising too slowly--turns out to be a non-starter. Also, the reader will also see that policy makers should take care not to enact policies based on the experience of a subset of colleges without considering their ramifications for colleges which have a very different experience. For instance, expanding the number of seats available in very selective colleges might reverse their rising selectivity but would likely steepen the decline in other colleges' selectivity.

\section{The Causes of Changing College Selectivity}

What could have caused students to make such different college choices that we see the fanning-out of selectivity that we observe? What could have caused initially selective colleges to become more selective in an environment where most colleges' selectivity was falling?

One important explanation for resorting is the increased willingness of students to attend college far from the homes of their parents. Anything that decreases the disutility generated by distance may cause students to match themselves to colleges on other bases, such as the resources or peers a college offers. Thanks to a combination of technological advances and increased competition, the cost of communicating and traveling over a long distance fell tremendously during this time. The cost of a 10-minute crosscounty telephone call in 2007 dollars (converted from Federal Communications Commission data using the Personal Consumption Expenditures price index with food and energy excluded) fell from $\$ 48.32$ in 1960 to $\$ 25.91$ in $1970, \$ 9.96$ in $1980, \$ 3.97$ in 1990 , and $\$ 2.61$ by 2005 . Similarly, the costs of long-distance travel as measured by airline revenue per 100 passenger air miles in 2007 dollars (converted from Federal Aviation Authority data as before) fell from $\$ 42.65$ in 1960 to $\$ 32.06$ in $1970, \$ 28.91$ in $1980, \$ 20.75$ in 1990 , and $\$ 13.05$ by 2005 .

However, a far more dramatic fall in costs occurred in the cost of information: colleges' information about students and, to a lesser extent, students' information about colleges. In 1955, there was no early national college aptitude test. Students and colleges simply did not know where students stood in the national distribution of high school graduates' 
achievement or aptitude. Colleges were highly dependent on feeder high schools whose standards they understood. Although 23 percent of students took the SAT in 1955, nearly all of these students took the exam between April and June of their senior year, too late to change their college-going plans.

In 1956, the National Merit Scholarship Qualifying Test (NMSQT), later renamed the Preliminary SAT or PSAT, was introduced and administered to 10th graders. This test and its associated scholarships not only generated dramatic integration in the distribution of U.S. merit aid, the test also provided information to students and colleges about each student's achievement, relative to the nation. Amazingly, the test went from informing 0 percent of future freshmen in 1955 to 60 percent in 1956 ! The introduction of the NMSQT also fueled a massive increase in SATtaking, so that the number of SAT takers per freshmen seat went from 23 percent to 94 percent in 10 years. See Table 2. (The 94 percent number is a bit hard to interpret because taking the exam once as a junior and once as a senior became popular during this period. For several years, the College Board double-counted such students, but then it stopped doing so. This is why the series looks non-monotonic when the, in fact, it probably rose monotonically.) In any case, all the indicators suggest that students were extremely hungry for information about their achievement.

On the colleges' side, there was an equal recognition that the cost of identifying qualified students had plunged. Table 2 shows that the number of colleges that required the SAT or ACT was a mere 143 in 1955. By 1965, the number had more than quintupled. The number doubled again between 1965 and 1980, and by 1990 it was 1839 colleges. ${ }^{8}$ This number

8 Table 2 shows indicators of colleges' demanding aptitude information on distant students and students' demanding the ability to broadcast their aptitude to distant colleges. Requiring the SAT or ACT is a sign that a college draws its students from a large number of high schools, most of which are so unfamiliar that a standardized test score is a better indicator of achievement than a high school transcript. Similarly, taking the SAT is an indication that a student wants to attend one or more colleges that do not have deep familiarity with his high school. That is, it is an expression of interest in distant colleges.

A high school transcript contains much more information than a standardized test score. Unfortunately, the information is relative to a standard that a college will not understand unless it draws very often from the high school. Thus, a college with a very local draw can be selective without requiring the SAT or ACT because it can use high school 
understates the true demand for entrance exams since even colleges that do not officially require the SAT or ACT may in fact be reluctant to admit students who do not provide one of them. Today, the number of colleges that obtain SAT or ACT scores from the majority of their applicants is about 20 percent larger than the number who require the tests (Annual Survey of Colleges, 2007). A school might prefer not to require the tests in order to defuse the anger of critics who believe there are racial or ethnic biases in the tests.

Although it is somewhat harder to quantify the decrease in students' costs of obtaining information about colleges, these costs also fell rapidly from the 1950s through today. Because my research is highly dependent on gathering information from college guides, no one could be more aware than I am of how much easier it was to become informed about colleges in the 1960s (when guides began routinely to include "hard" information on students' test scores and grades) versus the 1950s; how much easier it was again in the 1970s (when each guide sought to have nearly universal coverage) versus the 1960s; how much easier it was again in the 1980s (when the guides began to gather information in a uniform way) versus the 1970s; and so on. Today, the web contains an incredible volume of information about colleges, and the sites are set up so that students can easily find and compare the colleges that match their criteria.

In addition, the reporting required for financial aid became much more standardized starting in 1954, when the College Scholarship Service was founded. Standardization of financial reporting continued through the 1970s, when the modern financial aid form was introduced. Such standardization makes it significantly easier for students to apply to multiple colleges and compare them.

It is fairly intuitive that the falling costs of distance and information were the causes of integration, but can one show this? A demonstration has to be based on timing and which colleges and areas of the country resorted students earlier. For instance, the colleges that adopted standardized entrance exams earlier saw earlier increases in the homogeneity of their students' aptitude and earlier dispersion in the geography of their students' homes. Similarly, when a state switched policy

information well. Indeed, this is what every selective college did prior to the integration of the market for college education. In short, Table 2 should not be read as showing the number of colleges in the U.S. that are selective.

Similarly, Table 2 should not be read as showing the number of students in the U.S. interested in college. Many students attend local colleges without taking the SAT or ACT. 
so that standardized testing was required of most of its college-going students, it typically saw a jump in the percentage of students who attended college outside the state and the region. See Hoxby, 2005.

\section{A Note on Measures of College Selectivity}

The astute reader will now be able to see why I use test scores, rather than admissions rates, as a measure of colleges' selectivity. Since admissions rates are data that are much easier to obtain than test scores (see footnote 1), the choice is not one that I made lightly.

A college's admissions rate is, obviously, a function of the number of students who apply to it. In an environment where students' college choices are changing--as they have been shown to be changing--the meaning of an application is shifting and the admissions rate is therefore unreliable as a measure of selectivity. To give a simple example, suppose that, in the 1950s, each college-going student applied only to a single local college because his choice was constrained greatly by proximity. Suppose that, in recent years, each student applied to a "portfolio" of four colleges whose characteristics spanned those he wanted to consider. In this case, each college's admissions rate would have fallen four-fold even though some colleges' selectivity would have actually been rising and other colleges' selectivity would have actually been falling! This example differs from the truth only in so far as round numbers were used for simplicity. In 1967, The American Freshman survey reported that 43 percent of college freshman had applied to only one college and only 20 percent had applied to four or more (Pryor et al, 2007). In 2006, the same survey reported that only 18 percent of freshman had applied to only one college and 57 percent had applied to four or more. (The survey understates the share of students who apply to only one college because it samples no non-selective colleges and very few less selective ones.)

Admissions rates can also fall when selectivity is not rising because students apply to colleges for which they are not qualified and would never have been qualified. Suppose that every illiterate person in the U.S. applied to every college and that they were all summarily rejected. Would we say that selectivity had increased? Surely not. Rising selectivity means, by definition, that the threshold (on the basis of aptitude or some other attribute) has risen. Merely adding unqualified people to the pool does not change the threshold. To make the scenario less stark and more realistic, suppose that school counselors now encourage all students to apply to college, regardless of whether they have prepared themselves or whether they have a real interest in enrolling. (Counselors might feel that it was now socially "correct" to say that everyone should attend college even if it 
would actually be a bad investment for some. Since college is costly, both in terms of direct and opportunity costs, and since poorly prepared students usually drop out after having paid some of these costs, college is predictably a bad investment for some students.) If counselors induce many students to apply who then realize that they do not want to attend (or--more preciselyattend the colleges that will admit them since non-selective colleges will admit anyone with a high school degree or a GED), the admissions rate will fall even though no college has raised its selectivity.

In short, it is a logical fallacy that the admissions rate has a necessary equivalence with or even a monotonic relationship with selectivity. It has neither and should therefore not be used as an indicator of selectivity.

\section{Modeling the Market for College Education}

At this point, we have discussed the causes of college market integration and seen that a great deal of re-sorting of students took place. But, why need integration lead to a more stratified sorting, as opposed to some other form of sorting? Theory is useful not only for answering this question but for understanding implications of integration that go beyond student sorting.

The market for college education is usually modeled as a two-sided matching problem in which the efficient outcome allocates students to colleges based on students' ability to benefit from the type and magnitude of the human capital investment that the college offers. (If we pose the problem as one for the social planner, the planner maximizes the total output of society minus the total cost of the inputs invested in students.) Reducing the cost of distance increases the number of students and colleges in the match, and is--thereby--likely to increase the efficiency of each match. Reducing the cost of the information that each side has about the other has an even greater effect on match efficiency. This is because information directly increases the likelihood that potential matches are that actually efficient are known to both the student and college in question.

Allowing, then, that college market integration is likely to make matching more efficient, when would we expect more efficient matches to exhibit the re-sorting we actually see? It turns out that we need to have some form of complementarity between a student's own ability and a college's characteristics.

In Rothschild and White's $(1993,1995)$ seminal model, students vary on an ascending scale of aptitude and colleges vary in curricular type. A college with a higher curricular type employs increasingly expensive teaching methods that are disproportionately useful to high aptitude 
students. This disproportionately usefulness is the key complementarity assumption: more able students can invest in a more expensive type of college education (faculty, libraries, laboratories, etc.) before their marginal return to human capital falls to equal their discount rate. The model generates a student-college matching that is stratified--that is, vertically differentiated both on student aptitude and on college inputs.

Alternatively. a vertically differentiated matching can be generated by a complementarity in peer effects (more able students benefit more from interacting with high ability peers) or any of several other plausible sources of complementarity (Epple, Romano, and Seig, 2006; Courant, Resch, and Sallee, 2008). The key takeaway is that some such complementarity is produce a stable, stratified outcome. The complementarity guarantees that (in the absence of credit constraints) the lowest aptitude student admitted to a college would, if forced to bid against other students to keep his seat, outbid even the highest aptitude student who was denied admission.

The aforementioned models assume that there is a single dimension of aptitude on which students differ. But, of course, there may be multiple forms of aptitude: some students may have high aptitude in math, others may have high aptitude in language arts, and so on. To the extent that students have a similar overall level of aptitude but differ in the form it takes, the aforementioned models generate horizontally differentiated matching. (Horizontal differentiation means that colleges specialize in subjects. Vertical differentiation means that colleges specialize in educating students of a specific level of aptitude, a concept that only makes sense if there is such a thing as general aptitude.) In horizontally differentiated matching, colleges that specialize in science admit students based on their science aptitude, colleges that specialize in the humanities admit students based on their aptitude in the arts, and so on. Although integration of the college market has increased horizontal differentiation somewhat, the most obvious effect of integration has been vertical differentiation of undergraduate education.

A Rothschild-White type of model implies that high aptitude students are clustered together in colleges that offer high inputs and that charge correspondingly high tuition. In fact, the key result of their second paper is that a frictionless (costless distance and costless information), decentralized market in which colleges maximize profits would produce the same studentcollege matching as a social planner who was maximizing the net output of the economy. This efficiency result obtains because, in their model, students are paying for their own education; they have no reason to under- or 
overinvest; and prices ration colleges effectively. ${ }^{9}$ (In the Rothschild-White model, colleges, though profit-maximizing, always earn zero profits.)

The aforementioned models do not explain certain features of the market for college education: institutional tuition subsidies (the positive difference between the cost of the inputs a student receives and the tuition he pays), the role of endowments, and the fact that colleges need to ration their places through admission (not just price).

To explain these features, Hoxby (forthcoming) extends a Rothchild and White-type model and makes it intergenerational. In her model, each college has a "dynasty"--the dynasty being all of the alumni of the college. In the intergenerational model, each generation of students pays less than the full cost of their education at the time they attend college. This is the institutional subsidy. Although students in each generation graduate having received more inputs that they paid for, they later donate to the college and fund part of the education of later generations of the dynasty-just as previous generations did for them. This use of endowments is, in fact, characteristic of American colleges. Colleges need to admit students on aptitude--they cannot depend on price as a rationing mechanism---since the tuition that a student pays when enrolled is not great enough to justify the investment that the college makes in him. The college needs later gifts to "close the books" on a cohort, and the later gifts depend on aptitude.

Interestingly, an intergenerational model with endowments can also explain why market integration fuels a right skewness of the human capital investments offered by colleges. In the next section, I trace this and other implications of integration for colleges' resources, tuition subsidies, and tuition.

Before moving ahead, it is worth noting that it is harder to claim an efficiency result in an intergenerational model with endowments than in the static Rothschild-White model where student tuition covers the cost of inputs. This is because we have a solid understanding of how much tuition students should be willing to pay (we can invoke a standard model of human capital investment) but only a limited understanding of how many dollars alumni should be willing to donate. For now, let us set this efficiency question aside, noting that the intergenerational model predicts the main financial consequences that we actually observe. We will return to the question of efficiency at the end of the paper.

9 Of course, there are other reasons why college investments might be inefficient: failures in the market for financing college education, spillovers from the college education of some people onto others, and so on. 


\section{Consequences of the Changing Selectivity of American Colleges: the Resources Students Experience}

The resorting of students among colleges clearly caused high aptitude students to experience peers who were themselves increasingly of high aptitude. The reverse is true of students with low college aptitude. In addition, the resorting of students among colleges substantially increased the correlation between a student's aptitude and the resources invested in his college education, regardless of whether those resources are measured by instructional resources, faculty qualifications, college facilities, or other indicators.

Figure 2 shows colleges' real student-oriented resources per student over time. Colleges are grouped exactly as they were in Figure 1, from most to least selective in 1962. Student-oriented resources include spending on instruction, student services, academic support, and operation and maintenance of facilities. Student-oriented resources do not include spending on research, public services, hospitals, or other functions. ${ }^{10}$

Student-oriented resources were initially more similar among low and high selectivity colleges than they are today. In 1967, the lowest selectivity schools spent about $\$ 3900$ per student and the highest selectivity schools spent about $\$ 17,400$ per student. Resources per student thereafter fanned out, with the low selectivity schools' resources eventually reaching about $\$ 12,000$ per student and the highest selectivity schools' resources reaching about $\$ 92,000$. (Note that 2-year and no-exam four year colleges have much lower resources per student than the observably least selective four-year colleges.) Much of the fanning-out occurs because resources per student develop a notable right skew--that is, they rise faster at institutions that were initially most selective. Some of the apparent skew is due to the fact the same percentage growth rate will generate more absolute growth if a college starts with a higher base. However, the average annual growth rate of real resources per student was about 7 percent at the least selective colleges and about 13 percent at the most selective colleges. At the colleges in between, the growth rate rises monotonically from 7 to 13 .

In Figure 2, I show resources measured in dollars, but I could have shown figures that displayed very similar patterns for many sub-indices of

10 Some fraction of research and public service expenditures do benefit students, but--on the other hand--some fraction of administrative and facilities expenditures do not benefit students. There is no perfect way to divide expenditures. However, instructional expenditures greatly dominate student-oriented expenditures, and the figure would look similar if only they were included. 
resources, measured in non-monetary metrics: faculty-student ratios, the percentage of faculty with Ph.D.s, volumes in the library, square feet of student-oriented buildings (not including hospitals and other such buildings), and indices of the average faculty member's capacity (authorship of highly used textbooks, highly cited research, awards, and so on). All such resource indices fan out and develop a right skew.

Students' re-sorting themselves led to substantial increases in the aptitude-resource correlation for two reasons. First, because, at the beginning of the period of rapid integration, more selective colleges had greater resources per student, resorting led mechanically to an increased aptitude-resource correlation. Second, colleges' resources changed endogenously with their student bodies.

The mechanical effect (resorting of students, holding colleges' resources fixed) accounts for only about a quarter of the increase in the correlation between a student's measured aptitude and the resources devoted to his college education. The correlation between average aptitude (the absolute value of math and verbal SAT scores) and resources per student rose from 0.14 in 1967 to 0.57 in 2007. About a quarter of this change in correlation is due purely to resorting.

Thus, the endogenous effect (colleges' resources depend on their student bodies) accounts for three-quarters of the increase in the aptitude-resource correlation. Theory predicts that dependence occurs for several reasons. First, if higher aptitude students can earn the market rate of return on a larger human capital investment, then colleges that were initially selective will have found that their students, as they increased in aptitude, will have demanded (and been willing to pay for) better qualified faculty, better facilities, and otherwise improved quality of instruction. Second, when higher aptitude students make human capital investments, their returns are greater in absolute terms. Thus, if they donate some share of their returns to their colleges, their donations as alumni will be larger and will buy more resources for the next generation of students. Thus, higher aptitude students will benefit from greater gifts and will thus be able to finance larger investments in their human capital than they could probably finance on their own (with family money, loans, and so on). Third (and this is outside the models discussed above), external donors' dollars may flow toward institutions that enroll high aptitude students, most likely because donors think that their money will be more productive if directed toward an institution where an agglomeration of high quality faculty are working with smart students and state-of-the art resources.

The main take-away from the evidence in this section is that market integration and the consequent re-matching of students to colleges has 
generated tremendous differentiation in the size of the human capital investments that students make. While all four-year colleges offer greater human capital investments today than they did four decades ago, the magnitude of the investments for high aptitude students is striking. (Of course there is not a one-to-one equivalence between expenditures and human capital investments, but the vast increase in expenditures is due primarily to increases in instructional spending, not to spending on amenities such as recreational sports facilities.) Figure 2 shows us why so many people pay attention to the small number of colleges whose selectivity has risen over time: the "stakes" associated with being a very high aptitude student have risen tremendously.

A few caveats are in order.

Because investment differentials are increasingly correlated with students' aptitude, they are less correlated with other characteristics of students, such as their parental background. This can be shown explicitly but should be fairly evident because it is an almost automatic side-effect, given the imperfect correlation between aptitude and parental background. For instance, Hoxby and Long (1999) show falling correlation between 1960 and today between college investments and parents' income, parents' education, race, and Hispanic ethnicity.

When people speak of colleges' having rapidly rising per-student spending, they may be extrapolating from the most selective schools, whose annual rate of growth in resources was twice that of the least selective schools. One might still ask, however, why is per-student spending in less selective colleges' rising at all--albeit more modestly--when such colleges are no more selective today and often less selective than in the past? Here, there are a number of possible answers, but one part of the explanation may be the rise in the return to college education that appears to have stated in the 1980s. If the return is rising, the same aptitude student will want to invest more now than in the past. Another explanation is Baumol's (1967): college education is a non-traded service so that its cost rises with labor productivity in traded sectors, with which it must compete for workers. Baumol's argument has special force in higher education, which depends heavily on high aptitude, highly educated workers whose returns in traded sectors have grown especially rapidly over recent decades.

\section{Further Consequences of Changing Selectivity: the Amount Students Pay and Do Not Pay for College}

In the U.S. system of higher education, students (and their families) pay for only a share of their college education through tuition. The remaining payments are made by students later in life when, as alumni who earn 
returns on their human capital, they donate to private colleges and pay taxes that support public colleges. While the accounting is obviously not strict--a person can attend one college and later donate to or pay taxes that support another college--the entire system would collapse if, in the aggregate, people did not later repay the subsidies they received at the time they were enrolled. Subsidies are defined as the difference between the resources that a student experiences when enrolled (shown in the last section) and the tuition he pays.

Figure 3 shows the annual subsidy per student, in real terms, for colleges from 1967 to 2007 . Colleges are again grouped by their selectivity in 1962.

What strikes the eye in Figure 3 is the tremendous increase in real subsidies per student for colleges that were in the top three selectivity groups in 1962. In 1967, colleges with selectivity in the 91st through 95th percentiles had about the same real subsidies per student as the least selective colleges. By 2007, these very selective colleges had subsidies of $\$ 14,118$, twice as large as those in the least selective colleges. In 1967, colleges with selectivity in the 96th through 98th percentiles had real subsidies per student of $\$ 2509$, only modestly higher than the subsidies in the least selective colleges. By 2007, these extremely selective colleges had subsidies that were four times as large as those of the least selective colleges. Finally, the most selective colleges began with real subsidies that were about four times those of the least selective colleges and ended with subsidies about 10 times those of the least selective colleges. It is interesting to note that the annual real growth rate in subsidies averaged about 25 percent for all of the top three selectivity groups. They just started from different bases. Other selectivity groups had annual real growth rates in subsidies that averaged between 7 and 10 percent.

Even without seeing the calculations, the reader may be able to discern that tuition revenue has been falling as a share of student-oriented resources for the most selective colleges. Figure 4 makes this statement precise. The same groups of colleges are shown in the figure, but some groups are left out so that patterns are discernable. (Otherwise, the fairly similar patterns of colleges in the middling selectivity groups would obscure everything else.)

Average tuition paid as a share of student-oriented resources falls for every selectivity group, but the patterns differ. The least selective colleges start out with average tuition paid being about 60 percent of resources, and this statistic vacillates, ending up at about 44 percent. Most of these colleges are public colleges whose students have modest incomes. Thus, tuition paid is not a large share of resources because tax dollars make up 
the difference. Colleges at 51st through 60 th percentile of selectivity have tuition paid fall from 88 percent of resources to about 65 percent of resources. This is a substantial decrease but students at such colleges (and other middling selectivity colleges) continue to finance most of their own investments in human capital through the tuition they pay.

In contrast, students at the most selective colleges paid tuition equal to only 46 percent of their human capital investment even in 1967. By 2007, they were financing only 21 percent of their investment through tuition! The remaining colleges in the top decile of selectivity have students who finance more of their human capital investment (45 to 55 percent in 2007) but who also experienced a massive decrease in tuition paid as a share of resources, which was 75 to 100 percent in 1967.

The bottom line is that society is helping nearly all students make larger human capital investments by allowing them to pay for less up front and more in the future through donations or taxes. Nevertheless, most students still finance most of their human capital investment through tuition. It is only very high aptitude students who pay tuition that covers only a small share of the resources devoted to their education. The small share paid by these high aptitude students is particularly striking since the vast majority attend private colleges that have no ability to enforce repayment, through donations, of the massive subsidies they offer.

Are any students getting a windfall? On average and in equilibrium, the answer is probably no. The very high aptitude students experience massive subsidies but, on average, they pay them back. However, if a student whose true aptitude would not earn him admission to a very selective college can succeed in gaining admission by manipulating the information on his application, that student will get a windfall. It is no wonder, then, that students attempt various forms of manipulation. It is also no wonder that very selective colleges ration their seats on aptitude (not price) and try to ensure that students report accurate aptitude information on their applications.

Although very high aptitude students are not getting a windfall on average, they are much better off than they were under autarky. In autarky, they were the captives of their local college and routinely underinvested in human capital. With integration, they experience massive investments in their human capital, and it is colleges, not they or their families, that face most of the risk and difficulty associated with financing such vast investments. If high aptitude students do not actually earn much after attending a very selective college, they just do not donate much. It is up to the college to ensure that the books eventually balance for every cohort of students. Put another way, for high aptitude students, 
globalization represents a great release from market power. As they have become increasingly footloose, they have gained systemically.

A note on tuition growth, the subject of much policy debate, is in order. Studying time trends in tuition really only makes sense if (a) tuition generally pays for the resources students receive in college and (b) those resources have remained relatively constant over time. Neither of these conditions hold. We have seen that the average student pays tuition that covers only some of the resources he receives. Moreover, the resources he experiences have grown at a faster rate, in some cases a much faster rate, than tuition.

For instance, over the 1967 to 2007 period, the average annual growth rate of tuition paid was 5 percent at the least selective colleges, but the growth rate in their resources was 8 percent and the growth rate in their subsidies was 10 percent. Over the 1967 to 2007 period, the average annual growth rate of tuition paid was 6 percent at the most selective colleges, but the growth rate in their resources was 13 percent and the growth rate in their subsidies was 25 percent!

\section{On the Return to Attending a More Selective College}

All along, the discussion has assumed that students earn more if they invest in more human capital (for which they expect to have to pay, in one form or another). Is this the case? Do students actually earn a reasonable rate of return when they invest in a college with richer resources? This question is the subject of an empirical literature on the return to attending a more selective college.

The most credible studies are based on regression discontinuity or quasi-experimental designs. See, for instance Hoekstra (forthcoming) and Saavedra (2008). To illustrate these designs, consider Hoekstra's study of a state's flagship university that has a sharp admissions cut-off based on admissions exam scores. Because they are admitted if they apply, students who are just above the cut-off are much more likely to attend the flagship university than students who just below the cut-off. The latter group of students are not admitted (just!) and therefore attend less selective universities. Hoekstra uses administrative records to follow the earnings of people just above and just below the sharp cut-off. He finds an earnings difference that is so high that, even if we assume that the flagship students will have to pay back 100 percent of the larger subsidy they enjoy in college, their rate of return is a bit higher than the long-term return on equities. Of course, such regression discontinuity designs, though highly credible, have limitations: they produce estimated returns local to the set of people near 
the admissions cut-off and they cannot be applied to colleges that do not use sharp cut-offs but instead use holistic assessment for admissions. (Holistic assessment is the consideration of many student characteristics, including ones that can only be measured very subjectively, in a fashion that cannot be readily summarized by a formula. All of the most selective colleges in the U.S. use holistic assessment.)

Numerous moderately well-identified studies use straightforward regressions of earnings on college selectivity with a wide array of controls for students' high school preparation, aptitude, and parental background. See, for instance, Brewer et al (1996) or Monks (2000). Black and Smith (2006) stands out as the most sophisticated analysis in this vein. All of these studies tend to find rates of return that are around the long-term return on equities, even if we assume that students pay back 100 percent of the subsidy they receive. (Few of these studies directly account for what students pay in tuition and for the subsidies they receive. Thus, the reader must typically compute the rate of return for himself.) However, economists worry that such analyses may overestimate the return to attending a more selective college if they control insufficiently for characteristics, like motivation, that are hard to observe.

Finally, Dale and Krueger (2002) compute lower rates of return but their estimates are based on an identification strategy that is much less credible. They compare students who gained admission to approximately the same menu of colleges. They compare the earnings of those who, from within the same menu, chose a much more selective college and a much less selective college. However, since at least 90 percent of students who have the same menu similarly choose the more selective college(s) within it, the strategy generates estimates that rely entirely on the small share of students who make what is a very odd choice. These are students who know that they could choose a much more selective college and who have already expressed interest in a much more selective college (they applied). Yet, they choose differently than 9 out of 10 students. Almost certainly, these odd students are characterized by omitted variables that affect both their college decision and their later life outcomes.

The long and the short of it is that studies with moderate to strongly credible identification strategies suggest that the returns are such that the typical student is sensible when he applies to selective colleges and when he enrolls in one of the more selective colleges among those that offer him admission.

\section{Discussion and Conclusions}

Over the past few decades, the average college has not become more 
selective: the reverse is true, though not dramatically. The reason that initially selective colleges are much more selective today is not that they have failed to expand to absorb greater numbers of extremely high aptitude students. In fact, they have expanded modestly, keeping up with the modest growth in the population of such students.

To understand changing selectivity, we must focus how the market for college education has re-sorted students among schools as the costs of distance and information have fallen. The reason that initially selective colleges are much more selective today is that, in the past, students' choices were very sensitive to the distance of a college from their home but, today, students, especially high aptitude students, are far more sensitive to a college's resources and student body.

Because colleges' resources have responded endogenously to their changing student populations, the stakes associated with choosing a college are greater today than they were four decades ago. For very high aptitude students, the stakes are much greater. The very large per-student resources and per-student subsidies at very selective colleges enable such students to make massive human capital investments if they are admitted. Of course, these students do, on average, pay back the subsidies so that the next generation has the same or better opportunities. Nevertheless, a person who earns a solid rate of return on a massive investment is a person who is quite affluent.

Has the integration of the college market made students' human capital investments more efficient? In a static world in which each student paid in tuition for the inputs he received in college, the answer would almost certainly be yes. Integration would have increased efficiency by reducing the share of highly able students who made only modest investments in higher education simply because that is what their local college offered.

Of course, students' investments might be privately inefficient if they routinely miscalculate their own expected rates of returns, if there are failures in the capital market for financing higher education, or if they suffer from behavioral anomalies (like hyperbolic time preferences). Their investments might also be socially inefficient if one person's college education generates externalities for others. In other words, we can trot out all the usual reasons for private and social inefficiencies in education investments, but it would be such reasons--not integration of the college market--that would be responsible for the inefficiencies.

In an intergenerational world with college endowments, we can make parallel statements about efficiency if alumni and other donors give money to colleges based on assessments of the rates of return that the students will earn who are beneficiencies of their donations. For instance, in the 
interests of efficiency, we would like to see an alumnus stop giving money to his college if he realized that it was so overendowed that its students were earning low rates of return on the investment made in them. Similarly, in the interests of efficiency, we would like to see outside donors move their gifts toward the colleges that were generating the highest private and/or social returns on investment. To the extent that alumni and other donors

make gifts without assessing returns, we can generate scenarios in which some students receive inefficiently large investments in their college education.

\section{References}

American College Testing (ACT) Service. Annual Report. 1968 through 2008. Iowa City, IA: ACT, 1968 through 2008.

American College Testing (ACT) Service. ACT High School Profile Report: The Graduating Class of [various years] National. 1966 through 2008 editions. Iowa City, IA: ACT, 1966 through 2008.

Barron's. Barron's Profiles of American Colleges. 1964 and 1968 to 2007 editions. Great Neck and Woodbury, NY: Barron's Educational Series, Inc., 1964 and 1968 to 2007.

Baumol, William J. "Macroeconomics of Unbalanced Growth: the Anatomy of Urban Crisis," American Economic Review, 57 (1967), pp. 415-426.

Black, Dan A. and Jeffrey A. Smith, "Estimating the Returns to College Quality with Multiple Proxies for Quality," Journal of Labor Economics, 24.3 (2006), pp. 701-728.

Brewer, Dominic J., Eric Raymond Eide, and Ronald G. Ehrenberg, "Does It Pay To Attend An Elite Private College? Cross Cohort Evidence on the Effects of College Quality on Earnings," NBER Working Paper 5613, 1996

Brumbaugh, Aaron J. American Colleges and Universities. 1948 edition. Washington, DC: American Council on Education, 1948.

Cass, James, and Max Birnbaum. Comparative Guide to American Colleges. 1964 through 1971 editions. New York: Harper and Row, 
1964 to 1971.

Clotfelter, Charles T. Buying the Best: Cost Escalation in Elite Higher Education. Princeton, NJ: Princeton University Press, 1996.

College Entrance Examination Board. Annual Report. 1946 through 2007 editions. Princeton, NJ: College Entrance Examination Board, 1946 to 2007.

College Entrance Examination Board. 2008a. Annual Survey of Colleges. 1986 through 2007 editions. Electronic data. Princeton, NJ: College Entrance Examination Board, 1986 to 2007.

College Entrance Examination Board. 2008b. College-Bound Juniors and Sophomores. 2000 to 2008 editions. Princeton, NJ: College Entrance Examination Board, 2000 to 2008.

College Entrance Examination Board. College-Bound Seniors. 1971 to 2008 editions. Princeton, NJ: College Entrance Examination Board, 1971 to 2008.

College Entrance Examination Board. The College Handbook. 1941 to 1975 editions. Princeton, NJ: College Entrance Examination Board, 1941 to 1975 .

College Entrance Examination Board. Manual of Freshman Class Profiles. 1962 and 1967 editions. Princeton, NJ: College Entrance Examination Board, 1962 and 1967.

College Entrance Examination Board. On Further Examination: Report of the Advisory Panel on the Scholastic Aptitude Test Score Decline and Appendices. Princeton, NJ: College Board Publication Orders, 1977.

College Entrance Examination Board. SAT-ACT Concordance Tables: Concordance Study by ACT and the College Board. Webpage: http://professionals.collegeboard.com/profdownload/act-sat-concordancetables.pdf Retrieved August 2008.

College Entrance Examination Board. SAT Equivalence Tables: Convert Individual and Mean Scores from the Original Scale to the Recentered Scale. Webpage: http://professionals.collegeboard.com/data-reports - 
research/sat/equivalence-tables. Retrieved August 2008.

Courant, Paul N., Alexandra M. Resch, James M. Sallee. "On the Optimal Allocation of Students and Resources in a System of Higher Education," The B.E. Journal of Economic Analysis \& Policy: Vol. 8 : Issue 1 (Advances), Article 11, 2008.

Dale, Stacy Berg and Alan B. Krueger, "Estimating the Payoff to Attending A More Selective College: An Application of Selection on Observables and Unobservables," Quarterly Journal of Economics, 117.4 (November 2002), pp. 1491-1527.

Dorans, Neil J., and Dianne Schneider. Concordance Between SAT I and $A C T$ Scores for Individual Students. Princeton, NJ: College Entrance Examination Board, 1999.

Dorans, Neil J. Correspondences Between ACT and SAT I Scores. Princeton, NJ: College Entrance Examination Board, 1999.

Ehrenberg, Ronald G. Tuition Rising: Why College Costs So Much. Cambridge, MA: Harvard University Press, 2000.

Epple, Dennis, Richard Romano, and Holger Sieg. "Admission, Tuition, and Financial Aid Policies in the Market for Higher Education," Econometrica, 74.4 (2006), pp. 885-928.

Federal Communications Commission. Monitoring Report. 1990 to 2008 editions. Washington, DC: Federal Communications Commission, 1990 to 2008 .

Flanagan, John C., David Tiedeman, et al. Project Talent Public Use File 1960-1976 and College Codes Crosswalk (restricted). Electronic data. ICPSR version. Palo Alto, CA: American Institutes for Research [producer], 1979. Ann Arbor, MI: Inter-university Consortium for Political and Social Research [distributor], 2001.

Hawes, Gene R. The New American Guide to Colleges. 1962 and 1966 editions. New York: Columbia University Press, 1962 and 1966.

Hoekstra, Mark. "The Effect of Attending the Flagship State University on Earnings: A Discontinuity-Based Approach," The Review of Economics 
and Statistics, forthcoming.

Hoxby, Caroline M. Competitive New World: How American Colleges Learned to Compete and How They are Changing the World. Princeton, NJ: Princeton University Press, forthcoming.

Hoxby, Caroline M. "The Changing Market Structure of U.S. Higher Education," Harvard University manuscript, 2005.

Hoxby, Caroline M. "How the Changing Market Structure of U.S. Higher Education Explains College Tuition," NBER Working Paper 6323, 1997.

Hoxby, Caroline M. and Bridget Terry Long. "Explaining Rising Income and Wage Inequality Among the College-Educated," Harvard University manuscript, 1999.

Irwin, Mary. American Colleges and Universities. 1952 and 1956 editions. Washington, DC: American Council on Education, 1952 and 1956.

Marsh, Clarence S. American Colleges and Universities. 1940 edition. New York: Walter de Gruyter, 1940.

Monks, James. "The Returns to Individual and College Characteristics Evidence from the National Longitudinal Survey of Youth," Economics of Education Review, 19.3 (2000), pp. 279-289.

National Center for Education Statistics, Institute for Education Sciences, U.S. Department of Education. Digest of Education Statistics. 1995 through 2007 editions. Washington, DC: U.S. Department of Education, 1995 to 2007.

National Center for Education Statistics, Institute for Education Sciences, U.S. Department of Education. Education Longitudinal Study of 2002/06: Restricted Use Second Follow-up Data Files, Data File Documentation, and Electronic Codebook System. Electronic data. Washington, DC: U.S. Department of Education, 2007.

National Center for Education Statistics, Institute for Education Sciences, U.S. Department of Education. High School and Beyond: 1992 (Restricted) Data File. Electronic data. Washington, DC: U.S. Department of Education, 1995. 
National Center for Education Statistics, Institute for Education Sciences, U.S. Department of Education. Integrated Postsecondary Education Data System. Enrollment, Finance, Residence and Migration, and Institutional Characteristics files. 1980 and 1984 through 2008 editions. Electronic data. Washington, DC: U.S. Department of Education, retrieved August 2008 (except for 2008 data, which were retrieved January 2009).

National Center for Education Statistics, Institute for Education Sciences, U.S. Department of Education. NAEP 2004 Trends in Academic Progress: Three Decades of Student Performance in Reading and Mathematics. Washington, DC: U.S. Department of Education, 2005.

National Center for Education Statistics, Institute for Education Sciences, U.S. Department of Education. NAEP 2008 Long Term Trend. Online electronic data: http://nces.ed.gov/nationsreportcard/ltt/. Washington, DC: U.S. Department of Education, 2009.

National Center for Education Statistics, Institute for Education Sciences, U.S. Department of Education. NELS:88/2000 Restricted Use Data Files and Electronic Codebook - Base Year through Fourth Follow-up. Electronic data. Washington, DC: U.S. Department of Education, 2002.

National Center for Education Statistics, Institute for Education Sciences, U.S. Department of Education. National Longitudinal Study of the High School Class of 1972. Electronic data. Washington, DC: U.S. Department of Education, 1994.

National Merit Scholarship Corporation. Annual Report. 1956 through 2007-08 editions. Evanston, IL: National Merit Scholarship Corporation, 1956 to 2008.

National Merit Scholarship Corporation. The Merit Scholars of 1956. Evanston, IL: National Merit Scholarship Corporation, 1956.

National Merit Scholarship Corporation. Certificate of Merit Winners 1957. Evanston, IL: National Merit Scholarship Corporation, 1957.

Orchard House. College Admissions Data Service. 1962 through 2004 editions (name of annual publication varies slightly). Concord, MA: 
Orchard House, 1962 to 2005.

Peterson's Guides. Peterson's Guide to Undergraduate Study. 1971 through 2000 editions. Princeton, NJ: Peterson's Guides, 1971 to 2000.

Pryor, John, Sylvia Hurtado, Victor B. Saenz, Jose Luis Santos, and William S. Korn. The American Freshman: Forty Year Trends. Los Angeles: Higher Education Research Institute, UCLA, 2007.

Rothschild, Michael and Lawrence J. White, "The Analytics of the Pricing of Higher Education and Other Services in Which the Customers Are Inputs, The Journal of Political Economy, 10.3 (1995), pp. 573-586

Rothschild, Michael and Lawrence J. White, "The University in the Marketplace: Some Insights and Some Puzzles," in Charles T. Clotfelter, ed. Studies of Supply and Demand in Higher Education. Chicago: University of Chicago Press, 1993.

Saavedra, Juan. "The Returns to College Quality: a Regression Discontinuity Analysis." Harvard University manuscript, 2008.

U.S. Department of Education. Higher Education General Information System. Enrollment, Finance Statistics, Student Charges, Residence and Migration, and Institutional Characteristics files. 1966 through 1986 editions. Electronic data. Washington, DC: U.S. Department of Education, 1966 to 1986 (retrieved on various dates).

U.S. Federal Aviation Agency. FAA Statistical Handbook of Aviation. 1940 through 2007 editions. Washington, DC: U.S. Federal Aviation Agency.

Winston, Gordon C., "Subsidies, Hierarchy and Peers: The Awkward Economics of Higher Education, The Journal of Economic Perspectives, 13.1 (1999), pp. 13-36. 


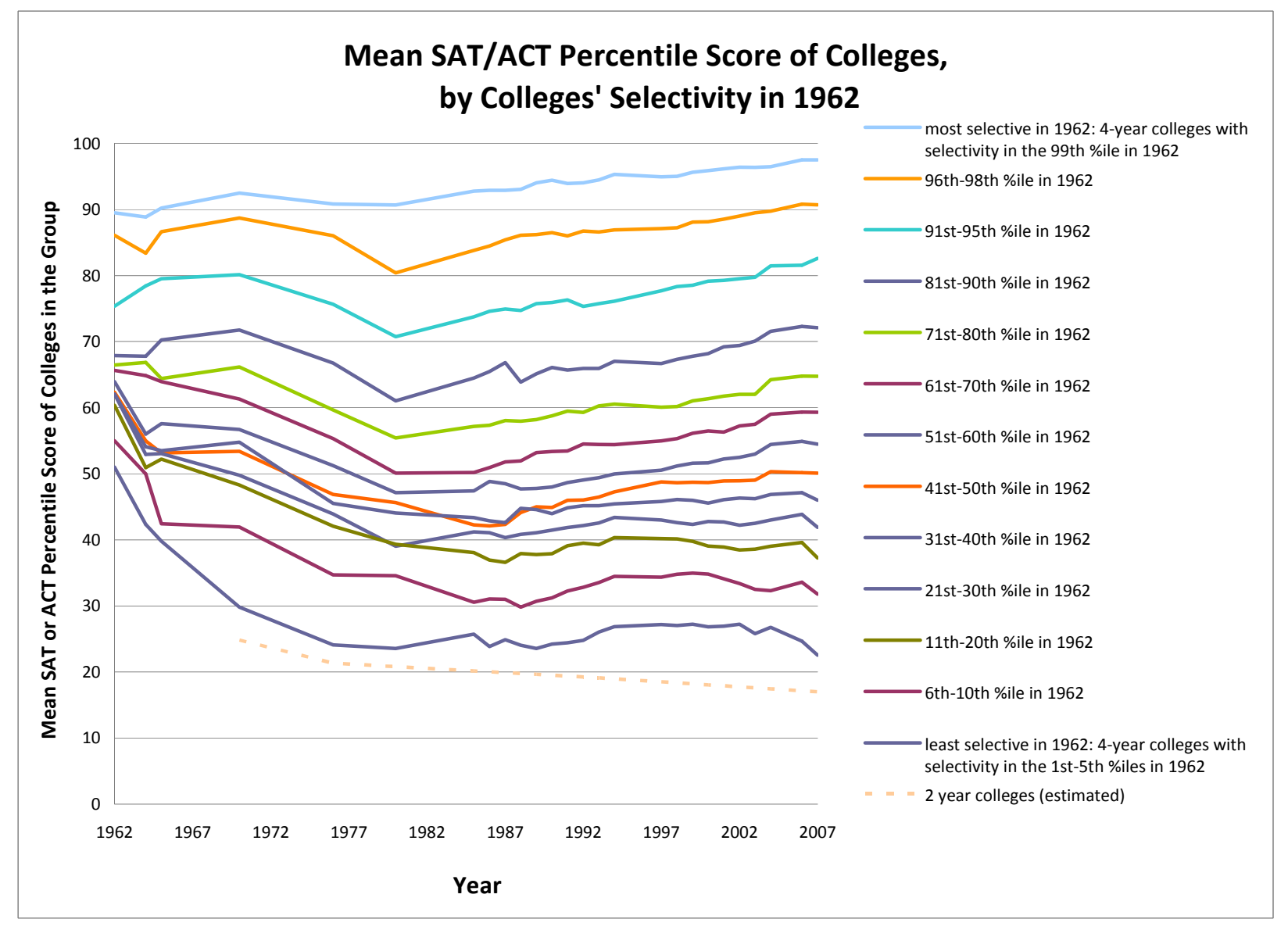

Figure 1 


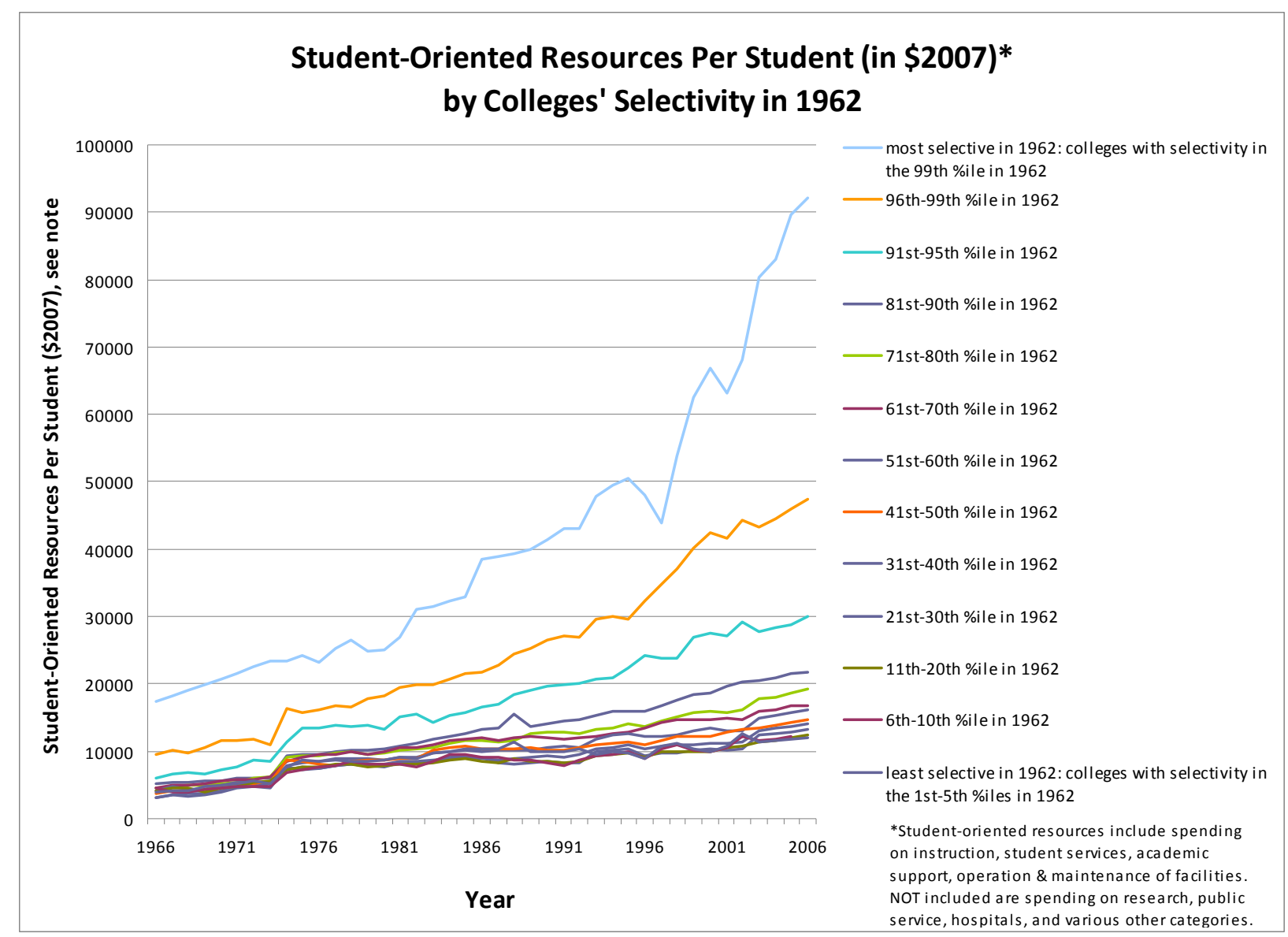

Figure 2 


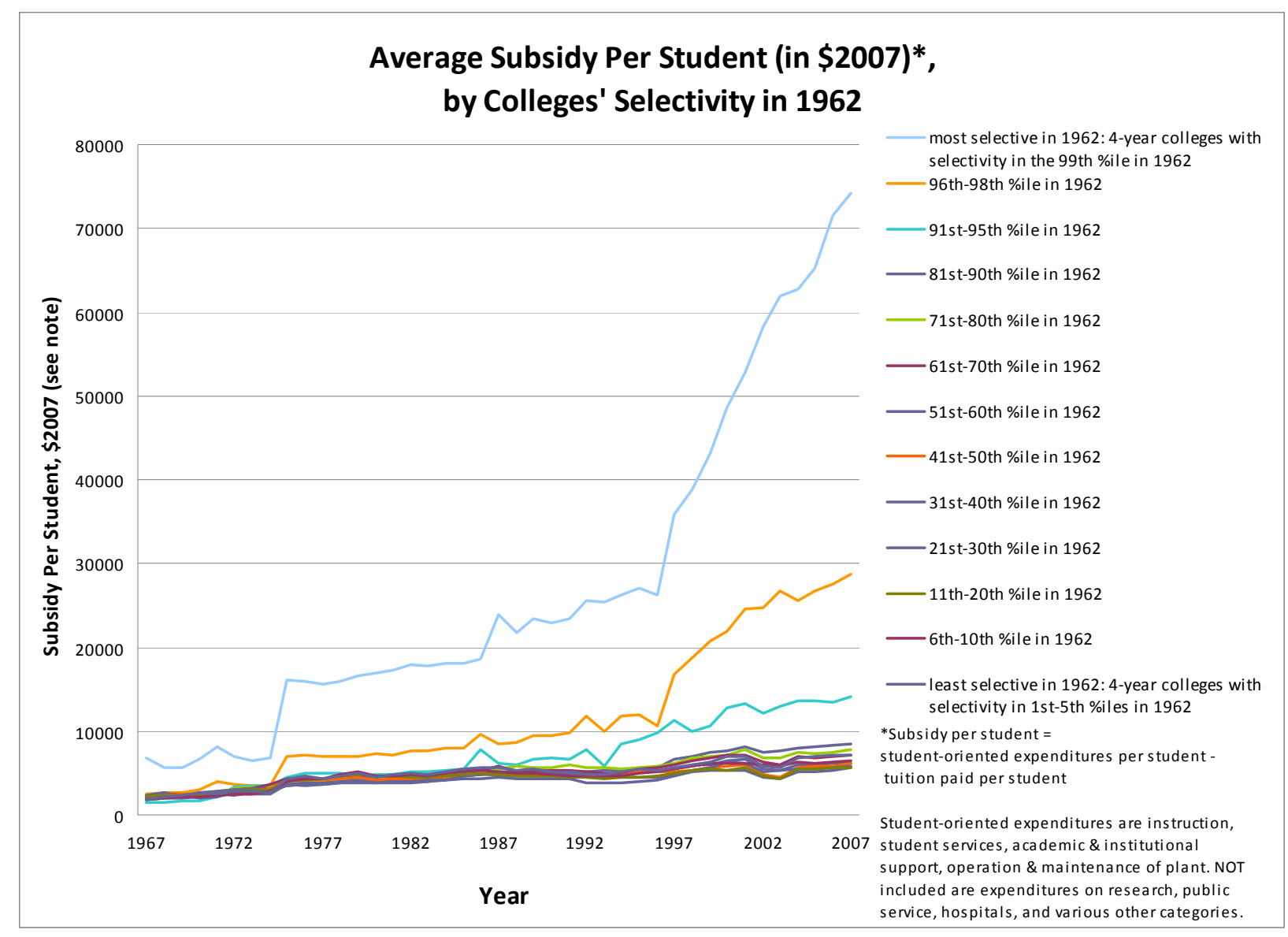

Figure 3 


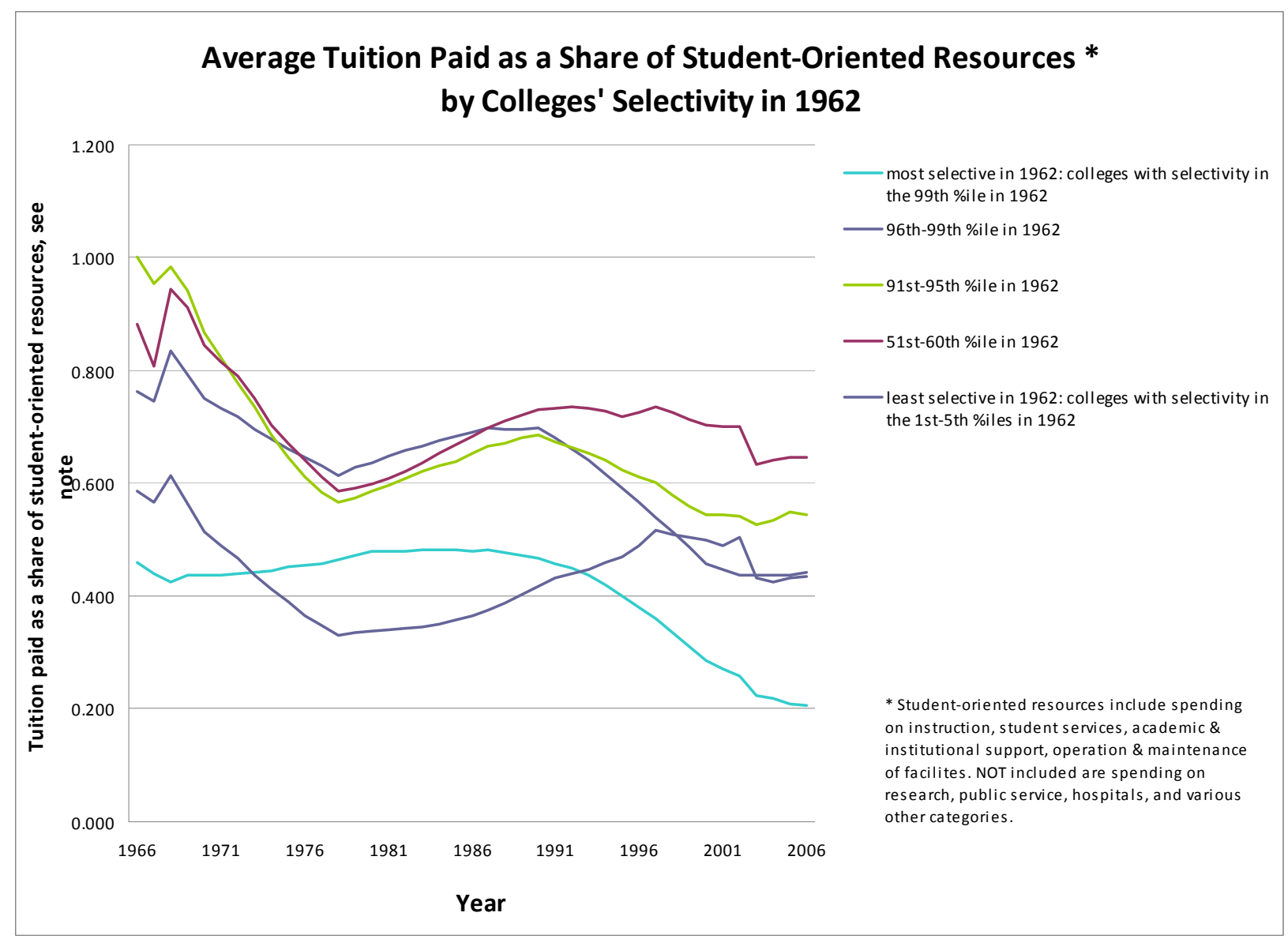

Figure 4 


\begin{tabular}{|c|c|c|c|c|}
\hline $\begin{array}{l}\text { high school } \\
\text { graduating } \\
\text { cohort }\end{array}$ & $\begin{array}{r}\text { number of } \\
\text { high school } \\
\text { graduates }\end{array}$ & $\begin{array}{r}\text { Table } 1 \\
\text { freshmen } \\
\text { seats }\end{array}$ & $\begin{array}{r}\text { number of } \\
\text { freshmen } \\
\text { seats per } \\
\text { moderately } \\
\text { college- } \\
\text { qualified } \\
\text { graduate } \\
\text { (see note) } \\
(3)\end{array}$ & $\begin{array}{r}\text { number of } \\
\text { freshmen } \\
\text { seats per } \\
\text { minimally } \\
\text { college- } \\
\text { qualified } \\
\text { graduate } \\
\text { (see note) } \\
(4)\end{array}$ \\
\hline 1955 & $1346^{\mathrm{e}}$ & 670 & . & \\
\hline 1960 & 1858 & 923 & . & \\
\hline 1965 & 2658 & 1442 & . & \\
\hline 1970 & 2889 & 2063 & 1.83 & 0.90 \\
\hline 1975 & 3133 & 2515 & 2.06 & 1.01 \\
\hline 1980 & 3043 & 2588 & 2.23 & 1.05 \\
\hline 1985 & 2677 & 2292 & 2.14 & 1.03 \\
\hline 1990 & 2589 & 2257 & 2.13 & 1.03 \\
\hline 1995 & 2520 & 2169 & 2.10 & 1.06 \\
\hline 2000 & 2833 & 2428 & 2.14 & 1.05 \\
\hline 2005 & 3103 & 2657 & 2.25 & 1.07 \\
\hline
\end{tabular}

e estimated.

Notes: The "baby boom" and "baby bust", not high school graduate rates, account for the dip and subsequent recovery in the number of high school graduates. The apparently anomolous numbers for 1980 in columns (3) and (4) are due to the dip in all U.S. students' achievement that occurred in the late 1970s and early 1980s. See the text for more on this dip and why it is best to ignore it if one is interested in selectivity. Moderately and minimally college-prepared twelfth graders score at or above, respectively, the Proficient and Basic levels on the National Assessment of Education Progress. See National Center for Education Statistics (2005).

Sources: National Center for Education Statistics, Digest of Education Statistics, various years; National Center for Education Statistics, NAEP Long Term Trend, 2009. 
Table 2

\begin{tabular}{lrr}
$\begin{array}{l}\text { high school } \\
\text { graduating } \\
\text { cohort }\end{array}$ & $\begin{array}{r}\text { number of } \\
\text { colleges } \\
\text { that require } \\
\text { the SAT or } \\
\text { ACT } \\
(5)\end{array}$ & $\begin{array}{r}\text { SAT } \\
\text { test-takers } \\
\text { per }\end{array}$ \\
\hdashline 1955 & 143 & 0.23 \\
1960 & 299 & 0.61 \\
1965 & 783 & 0.94 \\
1970 & 1112 & 0.75 \\
1975 & 1208 & 0.60 \\
1980 & 1451 & 0.58 \\
1985 & 1787 & 0.65 \\
1990 & 1839 & 0.69 \\
1995 & 1831 & 0.75 \\
2000 & 1476 & 0.81 \\
2005 & 1429 & 0.87 \\
\hline
\end{tabular}

e estimated.

Notes: Table 2 shows indicators of colleges' demanding aptitude information on distant students and students' demanding the ability to broadcast their aptitude to distant colleges. Table 2 should not be read as showing the number of colleges in the U.S. that are selective or the number of students in the U.S. interested in college. See footnote 8 for an explanation of this point.

The data in column (2) are somewhat problematic in 1960, 1965, and 1970, where apparent trends occur that are not actually meaningful. The problem is that students can take the SAT multiple times. Until 1975, the College Board double counted students who took the multiple times. Thus, SAT test-takers per freshman seat exaggerates the share of college-going students who took the SAT (since the numerator double counts students who took the SAT twice). The exaggeration is very small in 1955 and 1960, when very few students took the test before their senior year. The exaggeration was highest in 1965 and affects the 1970 number to a smaller degree. From 1975 onwards, the College Board eliminated double-counting by counting only unique students who took the SAT in their senior year.

Sources: National Center for Education Statistics, Digest of Education Statistics, various years; College Entrance Examination Board annual reports, various years. 